\title{
Mortality determination and gender identification of conceptuses in pregnancies of Santa Ines ovine by ultrasound
}

\author{
E.P.B.X. Moraes $^{1}$, L.M. Freitas Neto ${ }^{1}$, C.R. Aguiar Filho ${ }^{1}$, F.Q.G. Bezerra ${ }^{1}$, \\ M.H.B. Santos ${ }^{1}$, J.P. Neves ${ }^{2}$, P.F. Lima ${ }^{1}$ and M.A.L. Oliveira ${ }^{1 \#}$ \\ ${ }^{1}$ Laboratório de Biotécnicas Reprodutivas do Departamento de Medicina Veterinária, UFRPE, Av. Dom Manoel de \\ Medeiros s/n, Dois Irmãos, 52171 900, Recife/PE, Brazil \\ ${ }^{2}$ Faculdade de Agronomia e Medicina Veterinária, UNB, Campus Universitário Darcy Ribeiro/DF, Brazil
}

\begin{abstract}
The aim of this study was to monitor early gestation in Santa Ines ewes by ultrasound in order to determine embryo and foetal loss, and to identify foetal sex. Ewes $(n=132)$ were submitted to controlled natural mating. For the purpose of pregnancy diagnosis and embryo monitoring we used transrectal ultrasound with a linear transducer $(6.0$ and $8.0 \mathrm{MHz})$. Pregnancy was diagnosed on day 30 . On day 35 ultrasound examination was performed to determine embryo viability or loss. On days 40, 50 and 60 ultrasound examination was used to monitor foetal loss and to determine foetal sex, through identification of the genital tubercle or any external genital structure. Out of 118 pregnant ewes, $76(64.4 \%)$ presented single pregnancy and $42(35.6 \%)$ multiple pregnancy. Embryonic deaths occurred in 10.0\% of the 160 monitored embryos: 5.6\% (9/160) occurred during the embryonic phase and 4.4\% (7/160) during the foetal phase, with no significant difference between them. Embryo loss was significantly lower in single pregnancies $(3.9 \%$, $3 / 76)$ compared to multiple pregnancies $(15.5 \%, 13 / 84)$. Sexing accuracy on day 40 was significantly lower than on day 60. There was no difference between days 40 and 50, and between days 50 and 60 . This study on Santa Ines sheep shows that ultrasound is a highly effective method for diagnosis of early pregnancy, determination of embryo and foetal loss, as well as foetal sexing after day 50 of pregnancy.
\end{abstract}

Keywords: Ovine, embryo, foetus, genital tubercle

${ }^{\#}$ Corresponding author. E-mail: maloufrpe@uol.com.br

\section{Introduction}

Santa Ines sheep have drawn attention of agribusiness investors due to their rusticity, which allows the animals to withstand weather adversities without compromising productivity (Bandeira et al., 2004). Market demand has encouraged the introduction of technologies that improve reproductive efficiency in genetic breeding programmes. Said technologies require intense reproductive control, which can be achieved by ultrasound (Oliveira et al., 2004).

Despite its potential to rationalise productive capacity of herds (Santos et al., 2004b), foetal deaths were frequently attributed to ultrasound examination (Horder et al., 1986). Several studies focused on gestational loss, but Kaulfuss et al. (1997) were the first to report on the use ultrasound for the diagnosis of embryo mortality in ewes. Ultrasound has long been used as an efficient tool to monitor embryo loss, and is usually not associated with multiple pregnancy interruptions (Jainudeen \& Hafez, 2004).

Nowadays, the development of devices with improved image resolution (Reichenbach et al., 2004) has optimised early pregnancy diagnosis by ultrasound from day 23 through visualisation of the foetal heartbeat (Padilla-Rivas et al., 2005). The high rate of embryonic loss (25 to 40\%) in domestic species during early pregnancy (Immegart, 1997; Jainudeen \& Hafez, 2004) may result in false positive diagnosis (Buckrell, 1988), because embryos may not be confirmed in later examinations or at the time of birth (Chalhoub \& Ribeiro Filho, 2002).

Although not recommended, foetal sexing in Santa Ines ewes can be carried out between days 37 and 47 of pregnancy based on the genital tubercle (GT) position, or after day 50 based on the identification of external genital structures, regardless of the type of pregnancy (Santos et al., 2006), Bürstel et al. (2001) recommended two examinations for multiple pregnancies: the first between days 50 and 56 and the second between days 66 and 70 . 
The aim of this study was to determine foetal mortality and sex in Santa Ines sheep during the first 60 days of pregnancy. We hope to shed some light on the issue of early foetal loss and sexing in small ruminants.

\section{Material and Methods}

For the purpose of this study we used 132 Santa Ines ewes, aged two to four years, from two properties in Brejo da Madre de Deus, a city in the countryside of the state of Pernambuco. Conduct of the study was approved by the Universidade Federal Rural de Pernambuco Animal Care and Use Committee.

The ewes were raised in a semi-intensive system with access to native grass. The animals were also fed Cenchrus ciliaris, urocroa grass, the Leguminosae Prosopis juliflora (Swartz) DC, chopped Opuntia fícus-indica and a concentrate feed. Water and mineral salt were offered ad libitum.

Five ultrasound examinations were carried out, viz. on days 30, 35, 40, 50 and 60 of pregnancy, with the animals in a standing position. The transrectal ultrasound apparatus used in this study was a 240 Parus (Esaote Pie Medical - Maastricht/Netherlands) apparatus equipped with a linear transducer (6.0 and 8.0 $\mathrm{MHz}$ ) adapted on a PVC support to facilitate manipulation of the rectum of the animal, as suggested by Oliveira et al. (2004). Ultrasound images were printed on a Sony printer (Seikosha VP/1200 - Tokyo/Japan). All examinations were performed by the same technician.

Ultrasound evaluations were also performed on day 30 after mating in order to diagnose pregnancy and on day 35 after mating in order to confirm pregnancy and determine embryonic and foetal loss, as proposed by Santos et al. (2004a). On days 40, 50 and 60 of pregnancy ultrasound was carried out to determine foetal viability and loss, as reported by Kaulfuss et al. (1997), and to identify foetal sex by GT identification or visualisation of any external genital structure, according to Reichenbach et al. (2004).

The embryo and foetal loss, as well as the accuracy of gender identification, were statistically analyzed by the chi-square test with a significance level of $5 \%$.

\section{Results}

Of the 132 ewes examined, $118(89.4 \%)$ were pregnant. Of these $76(64.4 \%)$ presented single pregnancy and $42(35.6 \%)$ multiple pregnancy. The number of single pregnancies was significantly higher $(\mathrm{P}<0.05)$ than multiple pregnancies.

Conceptus death occurred in $10.0 \%$ of the 160 embryos: $5.6 \%(9 / 160)$ occurred during the embryonic phase and 4.4\% (7/160) during the foetal phase (Figure 1) without significant difference $(\mathrm{P}>0.05)$ between them. Embryo loss was significantly lower $(\mathrm{P}<0.05)$ in single pregnancies $(3.9 \%, 3 / 76)$ compared to multiple pregnancies $(15.5 \%, 13 / 84)$ (Figure 1).

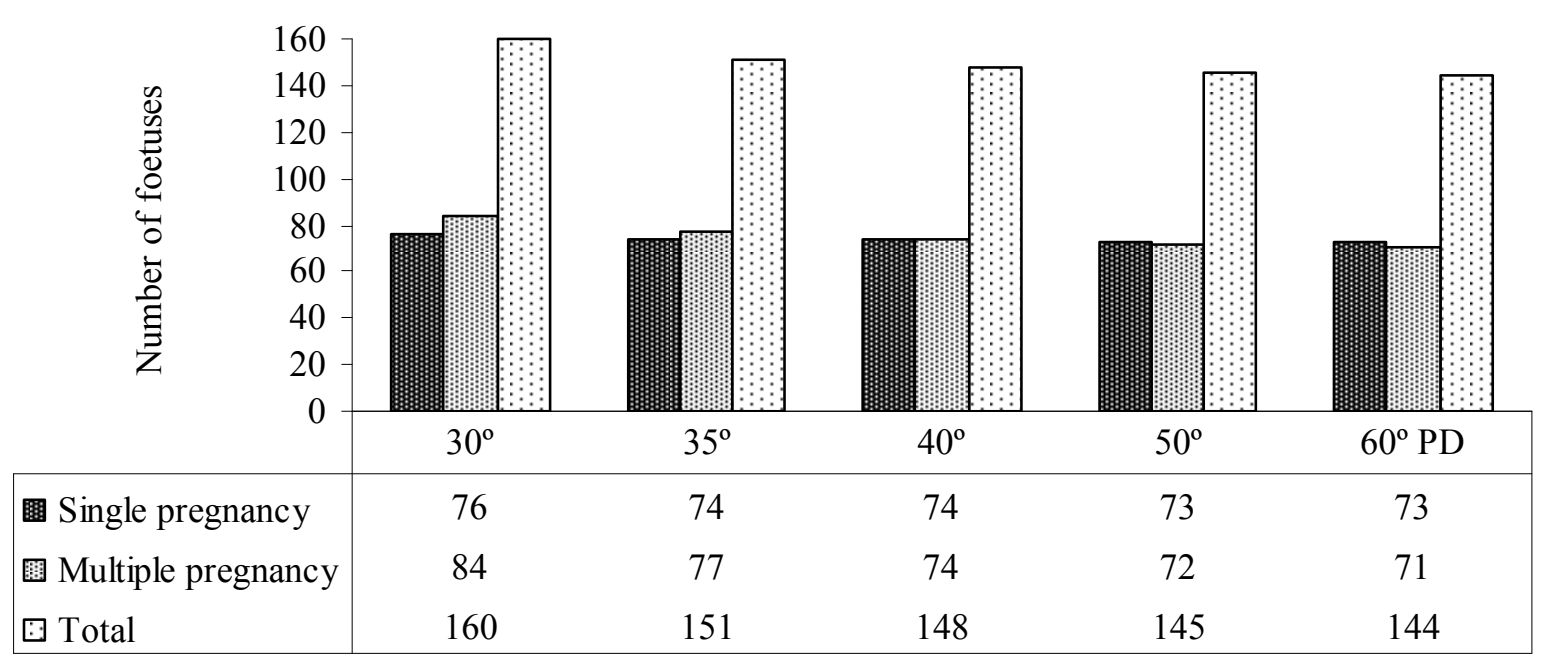

Figure 1 Embryonic and foetal losses during the first 60 days of pregnancy (PD) in Santa Ines ewes. 
Table 1 Gender identification of Santa Ines foetuses by ultrasonography carried out on days 40, 50 and 60 of pregnancy

\begin{tabular}{|c|c|c|c|c|c|c|c|}
\hline \multirow[b]{3}{*}{ Day } & \multicolumn{6}{|c|}{$P r e g n a n c y$} & \multirow[b]{3}{*}{$\begin{array}{c}\text { Accuracy } \\
\text { n (\%) }\end{array}$} \\
\hline & \multicolumn{3}{|c|}{$\begin{array}{c}\text { Single } \\
\text { Foetuses }\end{array}$} & \multicolumn{3}{|c|}{$\begin{array}{l}\text { Multiple } \\
\text { Foetuses }\end{array}$} & \\
\hline & $\begin{array}{c}\text { Correct } \\
\text { sexing } \\
n\end{array}$ & $\begin{array}{l}\text { Incorrect } \\
\text { sexing } \\
\mathrm{n}\end{array}$ & $\begin{array}{l}\text { Not } \\
\text { sexed } \\
\text { n }\end{array}$ & $\begin{array}{l}\text { Correct } \\
\text { sexing } \\
n\end{array}$ & $\begin{array}{c}\text { Incorrect } \\
\text { sexing } \\
\text { n }\end{array}$ & $\begin{array}{l}\text { Not } \\
\text { sexed } \\
\text { n }\end{array}$ & \\
\hline $40^{\circ}$ & 53 & 7 & 14 & 43 & 11 & 20 & 96/148 (64.9) aa \\
\hline $50^{\circ}$ & 62 & 2 & 9 & 53 & 3 & 16 & $115 / 145(79.3)$ \\
\hline $60^{\circ}$ & 68 & 1 & 4 & 58 & 2 & 11 & $126 / 144(87.5)^{b}$ \\
\hline
\end{tabular}

Dissimilar superscripts within columns denote differences $(\mathrm{P}<0.05)$.
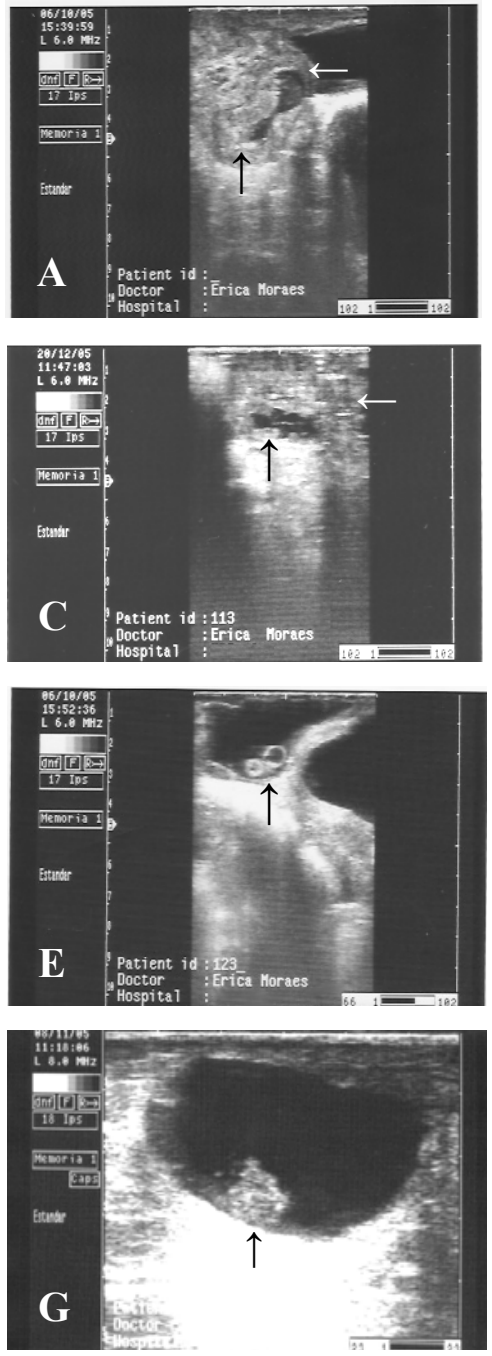
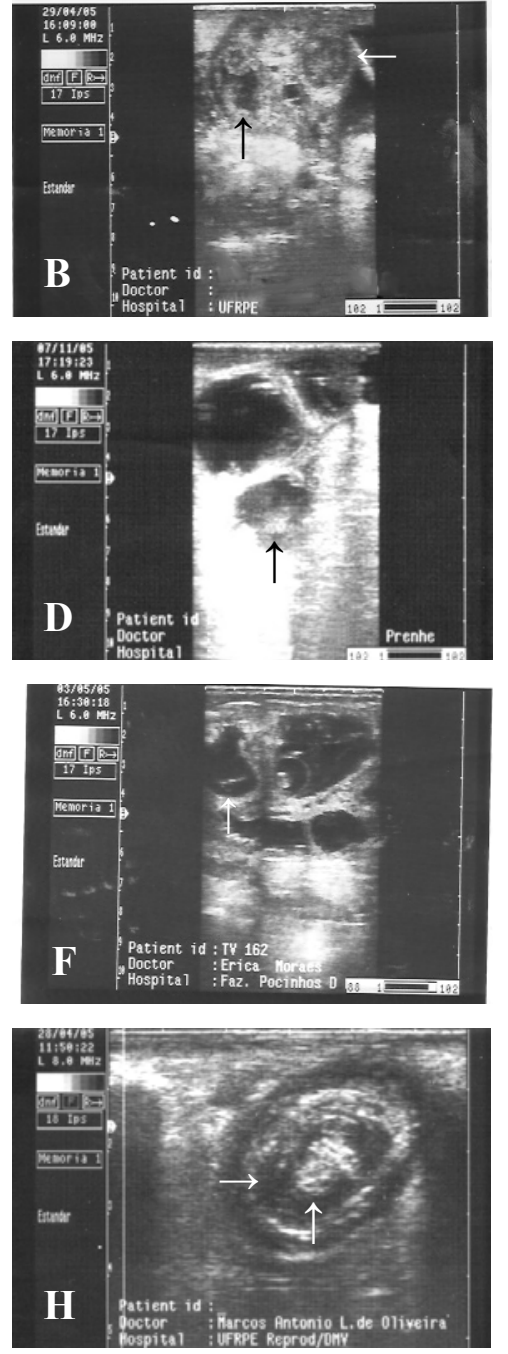

Figure 2 Early embryo loss (A, B, C) characterised by the ecogenicitity of the intra-uterine liquid $(\leftarrow)$ and by the undulation of the endometrium $(\uparrow)$. Late embryo loss (D, E, F) characterised by the absence of movement and heartbeat and the presence of a deformed foetus $(\uparrow)$. Initial $(\mathrm{G})$ and final $(\mathrm{H})$ processes of foetal loss characterised by the presence of deformed foetuses $(\uparrow)$ and reduction of liquid of the foetal vesicle $(\rightarrow)$. 

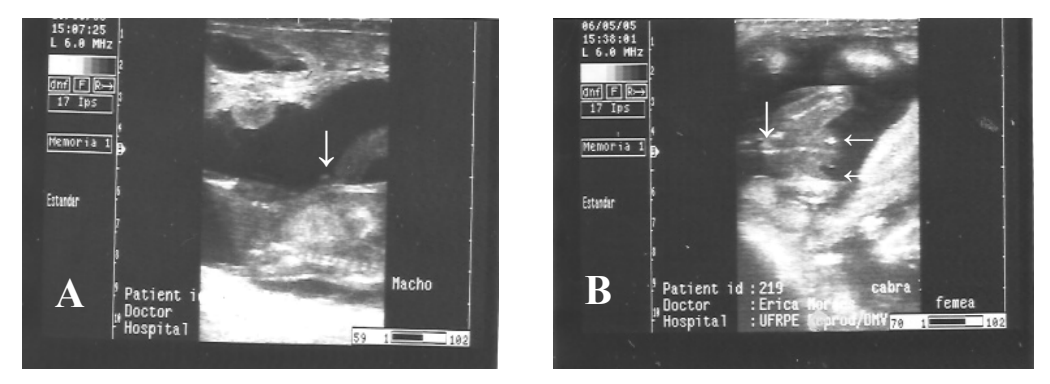

Figure 3 Visualisation of the genital tubercle in male $(\mathrm{A} \downarrow)$ and vulva $(\mathrm{B} \downarrow)$ and teats $(\mathrm{B} \leftarrow \uparrow)$ in the female foetuses.

Sexing accuracy on day 40 of pregnancy was significantly lower $(\mathrm{P}<0.05)$ than on day 60 . There was no difference $(\mathrm{P}>0.05)$ between days 40 and 50 , and between days 50 and 60 of pregnancy (Table 1). Figure 2 presents the images of early and late embryo loss and Figure 3 shows GTs and external genitalia of male and female foetuses.

\section{Discussion}

The pregnancy rate determined in this study is similar to that determined by Tainturier et al. (1983), Buckrell (1988), Haibel (1990), Aiumlamai et al. (1992), Garcia et al. (1993), Schrick \& Inskeep (1993), Chalhoub (2000) and Padilla-Rivas et al. (2005). This confirms the recommendations made by White et al. (1984) on the use of transrectal ultrasound examination in sheep as being a precise, rapid and safe method. Examinations were carried out during a phase of pregnancy that favours the determination of the number of embryos and the visualisation of important ultrasound parameters, such as foetal movement or heartbeat.

According to Immegart (1997) and Jainudeen \& Hafez (2004), the incidence of gestational loss in domestic species is higher in the beginning of the embryonic phase, and varies from 8 to $13 \%$ in sheep (Arthur, 1979). In the study by Arthur (1979) no difference was recorded between embryo and foetal loss, and the percentage of embryo loss was below these rates. Gestational loss is a result of natural selection for genotype that is more adapted to the environment (Arthur, 1979) and must be regarded as a normal process of elimination of inadequate genotypes, mainly from multiple pregnancies (Arthur, 1979; Jainudeen \& Hafez, 2004).

Similar to the findings of Arthur (1979) and Jainudeen \& Hafez (2004), we also found gestational loss to be more common in multiple pregnancies, and regarded it as a natural process. Related to this, Kleemann \& Walker (2005) observed that in Merino sheep gestational loss due to inadequate nutrition or high temperatures was more frequent in multiple pregnancies than in single ones.

The lowest accuracy in gender identification on day 40 of pregnancy could be due to the fact that in Santa Ines sheep GT migration occurs between days 37 and 46 (Santos et al., 2006). It is important to note that this nine-day period of GT migration is a long period, and can confuse the operator when differentiating between males and females, as occurred in this study. For this reason is it crucial to know the period of GT migration, even if the ultrasound examination operator is experienced and skilful.

It is also important to bear in mind that the distance covered by the GT from the initial to the final position is much shorter in female foetuses than in male ones. This difference explains why it is difficult to determine the sex in abattoir-derived foetuses (Reichenbach et al., 2004), and why it is even more difficult to correctly determine the sex of a 40-day-old foetus based exclusively on ultrasound images. To reduce false diagnosis, Bürstel (2002) and Reichenbach et al. (2004) suggested repeated examinations, or examination at a later time, which allows visualisation of the GT at its final location, or the identification of external genital structures.

The examinations carried out on days 50 and 60 of pregnancy confirmed these observations; there was no difference between foetal sexing. The accuracy on days 50 and 60 of pregnancy was more compromised 
by the foetal position, which impaired gender identification, than on day 40. Probably, if examinations had been repeated, as is recommended by Bürstel (2002) and Reichenbach et al. (2004), the percentage of correct diagnoses would be higher, especially in multiple pregnancies, where diagnosis is more difficult (White et al., 1984; Gearhart et al., 1988; Haibel, 1990). In the case of multiple pregnancies, Bürstel et al. (2001) propose two examinations, the first between days 50 and 56 of pregnancy, and the second between days 66 and 70.

In our study, the accuracy obtained in the examinations carried out on day 60 of pregnancy did not differ from that reported by Coughbrough \& Castell (1998) and Andrade et al. (2004), who performed one evaluation in single pregnancies, and Santos et al. (2006), who performed several examinations in multiple pregnancies. However, our findings are in disagreement with the findings of Bürstel et al. (2002), who reported that transrectal examination is not recommended for multiple pregnancies.

\section{Conclusion}

We conclude that ultrasound is a highly effective method for early pregnancy diagnosis, determination of embryo and foetal loss, and foetal sexing after day 50 of pregnancy.

\section{References}

Aiumlamai, S., Fredricksson, G. \& Nislfors, L., 1992. Real-time ultrasonography for determination the gestational age of ewes. Vet. Rec. 131, 560-562.

Andrade, J.C.O., Guido, S.I. \& Sousa, B.P.A., 2004. Fetal sexing in ewes. Acta Sci. Vet. 32, 185.

Arthur, G.H., 1979. Infertility in ovine. In: Reproduction and Veterinary Obstetrics. Ed. Arthur, G.H., $4^{\text {th }}$ ed., Guanabara Koogan, Rio de Janeiro. pp. 426-433.

Bandeira, D.A., Santos, M.H.B., Correia Neto, J. \& Nunes, J.F., 2004. Aspectos da caprino-ovinocultura no Brasil e seus reflexos produtivo e reprodutivo. In: Diagnóstico de gestação na cabra e na ovelha. Eds. Santos, M.H.B., Oliveira, M.A.L. \& Lima, P.F., Varela, São Paulo. pp. 1-9. (In Portuguese).

Buckrell, B.C., 1988. Application of ultrasonography in reproduction in sheep and goats. Theriogenology 29, 71-84.

Bürstel, D., 2002. Untersuchungen zur intrauterinen Geschlechtsfeststellung bei Feten kleiner Wiederkäuer mittels Ultrasonographie. PhD thesis, Reproduction Medicine Institute, School of Veterinary Medicine of Hannover, Germany. (In German).

Bürstel, D., Meinecke-Tillmann, S. \& Meinecke, B., 2001. Ultrasonographic determination of fetal sex in small ruminants. In: Proceeding of the Annual Conference of the European Society for Domestic Animal Reproduction, $5^{\text {th }}$, Vienna, Austria. pp. 53-54.

Bürstel, D., Meinecke-Tillmann, S. \& Meinecke, B., 2002. Ultrasonographic diagnosis of fetal sex in small ruminants bearing multiple fetuses. Vet. Rec. 151, 635-636.

Chalhoub, M., 2000. Aspectos ultra-sonográficos e aspecto hormonal da gestação ovina (Ovis aries) nas raças Bergamácia e ideal. PhD thesis, School of Veterinary Medicine and Zootechny, University of São Paulo, Botucatu, Brazil. (In Portuguese).

Chalhoub, M. \& Ribeiro Filho, A.L., 2002. Diagnóstico de gestação em pequenos ruminantes por ultrasonografia de tempo real. Rev. Bras. Reprod. Anim. 26, 27-30. (In Portuguese).

Coubrough, C.A. \& Castell, M.C., 1998. Fetal sex determination by ultrasonically locating the genital tubercle in ewes. Theriogenology 50, 263-267.

Garcia, A., Neary, M.K., Kelly, G.R. \& Pierson, R.A., 1993. Accuracy of ultrasonography in early pregnancy diagnosis in the ewe. Theriogenology 39, 847-861.

Gearhart, M.A., Wingfield, W.E., Knight, J.A., Smith, J.A., Dargatz, D.A., Boon, J.A. \& Stokes, C.A., 1988. Real-time ultrasonography for determining pregnancy status and viable fetal numbers in ewes. Theriogenology 30, 323-337.

Haibel, G.K., 1990. Use of ultrasonography in reproductive management of sheep and goat herds. Vet. Clin. North Am. Food Anim. Pract. 3, 597-613.

Horder, M.M., Barnet, S.B. \& Edwards, M.J., 1986. Diagnostic ultrasound in veterinary practice: How safe is it? Aust. Vet. J. 73, 10-15. 
Immegart, H.M., 1997. Abnormalities of Pregnancy. In: Current Therapy in Large Animal Theriogenology. Ed. Youngquist, R.S., W. B. Saunders Company, United Kingdom. pp. 113-129.

Jainudeen, M.R. \& Hafez, E.S.E., 2004. Falha reprodutiva em fêmeas. In: Reprodução Animal. Eds Hafez, E.S.E. \& Hafez, B., $7^{\text {th }}$ ed., Lippincott Williams \& Wilkins, Baltimore, USA. pp. 261-278. (In Portuguese).

Kaulfuss, K.H., May, J., Süss, R. \& Moog, U., 1997. In vivo diagnosis of embryo mortality in sheep by realtime ultrasound. Small Rumin. Res. 24, 141-145.

Kleemann, D.O. \& Walker, S.K., 2005. Fertility in South Australian commercial Merino flocks: relationships between reproductive traits and environmental cues. Theriogenology 63, 2416-2433.

Oliveira, M.A.L., Reichenbach, H.D., Santos, M.H.B. \& Tenório Filho, F., 2004. Aplicabilidade do scan B na reprodução de pequenos ruminantes. In: Diagnóstico de gestação na cabra e na ovelha. Eds. Santos, M.H.B., Oliveira, M.A.L. \& Lima, P.F., Varela, São Paulo. pp. 85-96. (In Portuguese).

Padilla-Rivas, G.R., Sohnrey, B. \& Holtz, W.E., 2005. Early pregnancy detection by real-time ultrasonography in Boer goats. Small Rumin. Res. 58, 87-92.

Reichenbach, H.D., Santos, M.H.B., Oliveira, M.A.L., Meinecke-Tillmann, S. \& Bürstel, D.M., 2004. Sexagem fetal na cabra e na ovelha por ultra-sonografia. In: Diagnóstico de gestação na cabra e na ovelha. Eds Santos, M.H.B., Oliveira, M.A.L. \& Lima, P.F., Varela, São Paulo. pp. 117-136. (In Portuguese).

Santos, M.H.B., Moraes, E.P.B.X., Guido, S.I., Lima-Verde, I.B., Rocha, J.M., Bezerra, F.Q.G., IunesSouza, T.C., Oliveira, M.A.L. \& Lima, P.F., 2004a. Pregnancy diagnosis in sheep using transrectal and transvaginal ways. Acta Sci. Vet. 32, 243.

Santos, M.H.B., Oliveira, M.A.L., Lima, P.F., Moraes, E.P.B.X., Chalhoub, M. \& Bicudo, S.D., $2004 b$. Diagnóstico de gestação por ultra-sonografia de tempo real. In: Diagnóstico de gestação na cabra e na ovelha. Eds. Santos, M.H.B., Oliveira, M.A.L. \& Lima, P.F., Varela, São Paulo. pp. 97-116. (In Portuguese).

Santos, M.H.B., Moraes, E.P.B.X., Guido, S.I., Bezerra, F.Q.G.B., Melo, A.N., Lima, P.F. \& Oliveira, M.A.L., 2006. Fetal sexing in Santa Inês ewes by ultrasonography. Ciência Rural 36, 573-578. (In Portuguese).

Schrick, F.N. \& Inskeep, E.K., 1993. Determination of early pregnancy in ewes utilizing transrectal ultrasonography. Theriogenology 40, 295-306.

Tainturier, D., Lijour, L., Chaari, M., Sarjjana, K.W. \& Le Net, J.L., 1983. Diagnostic de la gestation chez la brebis por échotomographie. Rev. Med. Vet. 134, 523-526. (In Portuguese).

White, I.R., Russel, A.J.F. \& Fowler, D.J., 1984. Real-time ultrasonic scanning in the diagnosis of pregnancy and determination of fetal numbers in sheep. Vet. Rec. 115, 140-143. 